\title{
Mapping of Viral Genomic Regions Important in Cross-Protection Between Strains of a Potyvirus
}

\author{
Jari P. T. Valkonen, ${ }^{1,2}$ Minna-Liisa Rajamäki, ${ }^{1,2}$ and Tuija Kekarainen ${ }^{1}$ \\ ${ }^{1}$ Department of Plant Biology, Genetics Centre, SLU, PO Box 7080, S-750 07 Uppsala, Sweden; and ${ }^{2}$ Department of \\ Applied Biology, Plant Pathology Laboratory, P.O. Box 27, University of Helsinki, Finland.
}

Submitted 7 January 2002. Accepted 15 March 2002.

\begin{abstract}
Cross-protection was tested between potato and tobacco strains of Potato virus A, a member of the genus Potyvirus (PVA), in tobacco plants. Cross-protection was effective only at the initiation of infection. The potato strains provided only weak cross-protection against the tobacco strain, whereas the tobacco strain provided strong crossprotection against potato strains. The tamarillo strain (TamMV) showed cross-protection phenotypes mostly resembling those of the potato strains. Chimera of the PVA strains were utilized to map viral genomic regions important for cross-protection. The coat protein (CP) encoding region and the helper component proteinase (HCpro) affected cross-protection and virus accumulation. An amino acid substitution at the $\mathrm{CP} N$-terminus reduced virus accumulation and the ability to overcome cross-protection, whereas amino acid substitutions introduced to the HCpro increased virus accumulation and the ability to overcome cross-protection. Closer sequence relatedness between the protector and challenger isolate, as determined by the CPencoding sequence, was correlated with an increased crossprotection ability. Cross-protection was not overcome by inoculation with nonencapsidated viral RNA. Thus, the differences in cross-protection abilities between PVA strains and chimera were not explained with the "re-encapsidation model" described for strains of Tobacco mosaic tobamovirus but may be associated with a virus infection-induced RNA silencing mechanism.
\end{abstract}

Cross-protection is a phenomenon in which systemic infection of a plant with one virus (the "protector") prevents infection with another virus (the "challenger") (McKinney 1929). In this article, the term cross-protection is used to indicate interference between strains of the same virus species (Bos 1999; Fraser 1998), rather than any virus-induced host responses that may protect the plant against new infections with viruses and other pathogens (Valkonen 2002). Cross-protection can be used in virus disease management by inoculating attenuated virus strains to crop plants to prevent infection with more severe strains (Gonsalves 1998; Rast 1972; Rezende and Pacheco 1998). Its occurrence between virus strains also has been used as an indicator of relatedness (Bos 1999; Matthews 1991). However, the viral genes and genomic sequences playing a role in cross-protection and the reasons for its narrow ef-

Corresponding author: Jari Valkonen; Telephone: +46 1867 3372; Fax: +46 1867 3392; E-mail: jari.valkonen@ vbiol.slu.se

Current address of Tuija Kekarainen: Department of Molecular Cell Biology, Leiden University Medical Center, P.O. Box 9503, 2300 RA Leiden, The Netherlands. fectiveness to related viruses (strains) are unknown in most cases.

Cross-protection described for strains of Tobacco mosaic tobamovirus (TMV) is explained with a model postulating that disassembly of the challenger strain is prevented at entry to the cell because the protector strain coat protein $(\mathrm{CP})$ produced in these cells reencapsidates viral RNA (Lu et al. 1998). The model is supported with data showing that RNA binding by the $\mathrm{CP}$ is required for cross-protection, and stronger $\mathrm{CP}-\mathrm{CP}$ interactions enhance cross-protection ( $\mathrm{Lu}$ et al. 1998). Furthermore, expression of different mutants of TMV CP in transgenic tobacco plants shows that a stronger $\mathrm{CP}-\mathrm{CP}$ association is correlated with enhanced resistance to TMV (Beachy 1999). Thus, according to the "reencapsidation model," the CP is a likely effector of cross-protection.

Some studies have indicated that CP-less TMV strains can cross-protect against other TMV strains (Gerber and Sarkar 1989). Also, some reports indicate that the "green islands" developing in TMV-infected tobacco leaves lack detectable amounts of the virus and are cross-protected against new TMV infections (Matthews 1991). These results suggest that other mechanisms besides the CP-mediated mechanism could be involved in cross-protection. Recently, Xie and associates (2001) have provided a link between the development of green islands in TMV-infected tobacco leaves and posttranscriptional gene silencing (PTGS). PTGS is a cytoplasmic RNA surveillance mechanism found in all multicellular organisms (Cogoni and Macino 2000; Elbashir et al. 2001; Waterhouse et al. 2001). It is induced by double-stranded RNA (dsRNA), including RNA viruses that replicate via double-stranded intermediates, and results in a sequence-specific RNA degradation. In plants, PTGS constitutes a natural virus resistance mechanism (Mourrain et al. 2000; Waterhouse et al. 2001). The host factors shown to be required for PTGS in plants include an RNA-dependent RNA polymerase (RdRp) (Dalmay et al. 2000b; Mourrain et al. 2000), an RNA helicase (Dalmay et al. 2001), translation initiation factor eIFC2 (Fagard et al. 2000), and a calmodulin-related protein (Anandalakshmi et al. 2000). Xie and associates (2001) showed that silencing of the tobacco gene NtRDRPl for an RdRp increased the accumulation of TMV in tobacco plants. Furthermore, the leaves were more uniformly infected with TMV and no green islands developed. Thus, tobacco leaves infected with TMV seem to be cross-protected against TMV by two spatially separated mechanisms: the CP-mediated inhibition of virion disassembly in the chlorotic areas, and PTGS-based degradation of viral RNA in the green islands. It is characteristic for the green islands, other cross-protection situations, and transgenic plants (transformed with viral sequences) expressing PTGS-based virus resistance that resistance is narrow, (i.e., effective to virus strains with highly 
similar sequences) (Dougherty and Parks 1995; English et al. 1996; Matthews 1991). Therefore, it is plausible that PTGS is involved in many instances of cross-protection (Ratcliff et al. 1999).

Bearing the two prevailing models of cross-protection in mind, the aim of this study was to identify specific regions in the genome of Potato virus A, a member of the genus Potyvirus (PVA), which are important for cross-protection. To achieve this, we choose to use chimera constructed between PVA isolates, which appears to be a novel approach in crossprotection studies. The reason for not using expression of single viral proteins in transgenic plants was that it may result in cross-protection phenotypes different from those of replicative viral genomes (Angell and Baulcombe 1997; Yamaya et al. 1988). On the other hand, expression of viral proteins from heterologous viral genomes, such as a gene vector based on Potato virus $X$, a member of the genus Potexvirus ( $\mathrm{Lu}$ et al. 1998), possesses a possible disadvantage because co-infection with heterologous viruses may alter cellular physiology and affect the mechanisms involved in cross-protection. For example, potexviruses and potyviruses encode proteins that suppress different stages of the PTGS (Brigneti et al. 1998; Voinnet et al. 2000).

PVA is a typical member of the largest genus of plant viruses (genus Potyvirus, family Potyviridae). It has a messenger-polarity single-stranded RNA genome (Fig. 1) that resembles plant mRNAs. It contains a single open reading frame, $5^{\prime}$ and $3^{\prime}$-terminal nontranslated regions, and a poly(A) tail at the $3^{\prime}$ end. The viral RNA is readily translatable in cytoplasm at virion disassembly. It encodes a polyprotein that is processed into up to 10 mature proteins by three viral proteinases (Fig. 1). In this study, cross-protection was tested between genetically and biologically different strains of PVA in a host plant (tobacco) common for all these strains. The "tobacco strain" consisted of PVA isolates B11, Ali, Dat, and 716/12 with independent origins and which have been propagated in Nicotiana spp. since their isolation from potato over 20 years ago. They show high sequence identity ( $>99 \%$ for the CP-encoding region) (Table 1) and form a single genetic strain according to phylogenetic analyses (Rajamäki et al. 1998). In contrast, PVA strains Can, M, U, and Sab have been maintained in potato cultivars (Solanum tuberosum L.) since their isolation from potato. These "potato strains" are a heterogeneous group (96.4 to $99.3 \%$ ) (Table 1) (Rajamäki et al. 1998). Sequence identities between the potato and tobacco strains are rather low, ranging from 96.0 to $97.7 \%$ (Table 1), and the tobacco strain accumulates to much higher titers than the potato strains in tobacco plants (Andrejeva et al. 1999; Rajamäki et al. 1998). The PVA strain TamMV was obtained from tamarillo (S. betaceum Cav.) (Eagles et al. 1990) and is the most different of all PVA isolates (identity 86.9 to $88.8 \%$ ) (Table 1) (Kekarainen et al. 1999; Rajamäki et al. 1998). The data obtained in this study indicate that cross-protection in PVA is mediated by the $\mathrm{CP}$ encoding region and the HCpro. The data are more compatible with a PTGS model of cross-protection than the re-encapsidation model.

\section{RESULTS}

\section{Cross-protection between PVA isolates.}

The potato strain Sab is not detected with monoclonal antibody (MAb) 58/0, in contrast to other PVA isolates included in this study (Table 2). Thus, the ability of other isolates to overcome cross-protection in plants infected with Sab could be conveniently tested using MAb 58/0. Sab provided $100 \%$ protection against systemic infection with the potato strains $\mathrm{U}, \mathrm{M}$, and Can (Fig. 2, Table 3A). It also provided high levels of protection $(75 \%)$ against the tamarillo strain TamMV (Fig. 2, Table $3 \mathrm{~A}$ ). In contrast, the tobacco strain (isolates Ali, B11, Dat, and 716/12) could overcome cross-protection in most plants infected with Sab (Fig. 2, Table 3A). In the reciprocal protection tests, the tobacco strain (isolates Ali and B11) provided $100 \%$ protection, TamMV provided incomplete albeit high levels of protection $(75 \%)$, but the potato strain $\mathrm{M}$ provided no crossprotection against Sab (Table 3B). The CP sequence dissimilarities are indicated in Figure 2 to point out that cross-protection was not predictable simply based on the sequence identities between Sab and the challenger isolates (discussed below).

In the next experiments, the isolate B11 (tobacco strain) was used as a protector. It provided $100 \%$ protection against the

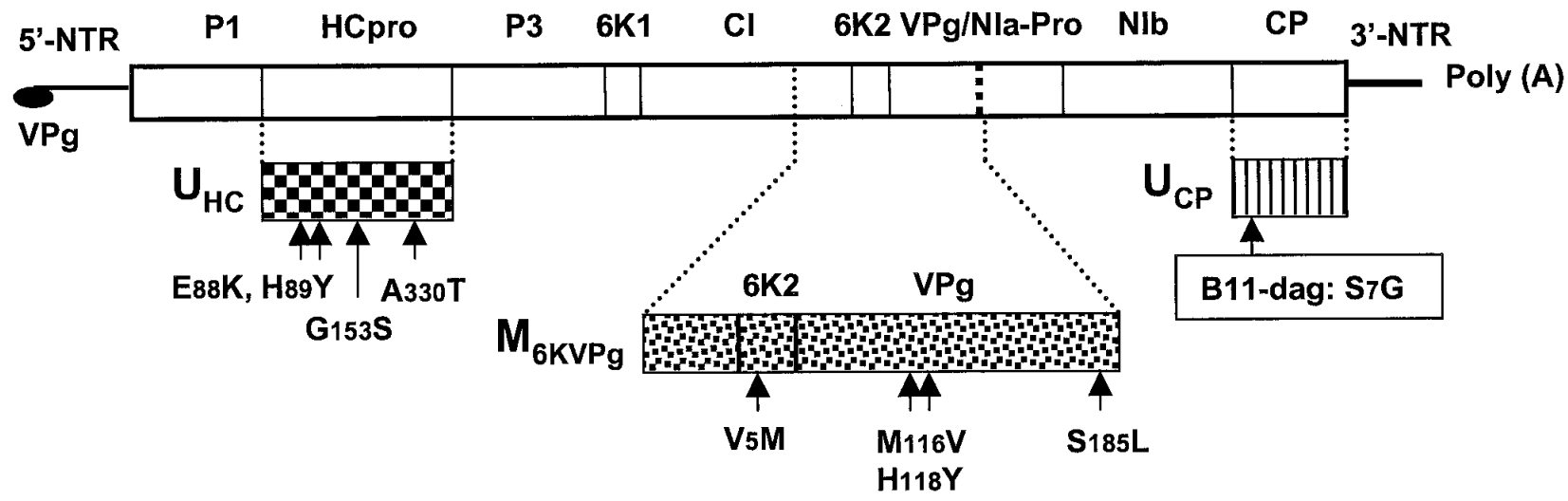

Fig. 1. Schematic presentation of the polyprotein (3,059 amino acids) encoded by the single open reading frame of the messenger-polarity single-stranded RNA genome (9,565 nt) of Potato virus A (PVA), isolate B11. The 10 mature proteins autocatalytically processed from the polyprotein (Kekarainen et al. 1999; Puurand et al. 1994) are: P1, proteinase; HCpro, helper component-proteinase; P3, the third protein; 6K1 and 6K2, 6-kDa proteins 1 and 2, respectively; CI, RNA helicase; VPg, the genome-linked protein; NIa-Pro, proteinase; NIb, RNA-dependent RNA polymerase (RdRp; replicase); CP, coat protein. The P1 protein and the HCpro separate themselves from the polyprotein. NIa-Pro catalyzes the cleavages at all other sites. $5^{\prime}$-nontranslated region (NTR) and 3'-NTR are 160 and 227 nt, respectively. The VPg is covalently linked to the 5'-NTR and found in virions of PVA (Oruetxebarria et al. 2000). PVA mutants containing amino acid substitutions in the HCpro, 6K2, VPg, or CP (highlighted) were constructed using an infectious cDNA of isolate B11 (Puurand et al. 1996) and have been described in detail (Andrejeva et al. 1999; Rajamäki and Valkonen 1999). The names of the mutants in the text refer to the mutated proteins, which are designated as: $\mathrm{U}_{\mathrm{HC}}, \mathrm{HCp}$ ro of B11 mutated at four positions according to the HCpro of isolate $\mathrm{U}_{\text {; }} \mathrm{M}_{6 \mathrm{KVg}}$, a genomic fragment (1,208 nt) containing the domains for the $6 \mathrm{~K} 2$ protein and VPg replaced with the corresponding genomic fragment of isolate $\mathrm{M}$ (four amino acid substitutions compared with $\mathrm{B} 11$ ); $\mathrm{U}_{\mathrm{CP}}$, the entire $\mathrm{CP}$-encoding region replaced with the corresponding region of isolate $\mathrm{U}$; and B11-dag, a single amino acid substitution introduced to the $\mathrm{CP}$ of $\mathrm{B} 11$. 
potato strains $\mathrm{Can}, \mathrm{Sab}$, and $\mathrm{U}$, but no protection against the tamarillo strain TamMV (Table 3C, Fig. 3). In the reciprocal tests, $\mathrm{U}$ and TamMV provided no protection against B11 (Table 3D) and, as already mentioned, only a few plants infected with Sab were protected against B11 (Table 3A).

We verified that cross-protected plants could be scored based on the apparent lack of infection in the upper non-challenge-inoculated leaves, because in such plants the challengeinoculated leaves also tested negative for the challenger isolate [tests carried out using the sensitive enzyme-linked immunosorbent assay (ELISA) and the two MAbs that distinguished Sab and the isolates Ali, B11, Dat, and TamMV (Table 2)]. On the other hand, in controls (not infected with the protector isolate), the challenger isolate was readily detected in inoculated and upper noninoculated leaves in all plants, which showed that lack of infection was due to cross-protection. These data indicated that cross-protection was effective at an early stage of infection in the challenge-inoculated leaves.

The leaves needed to be systemically infected with the protector isolate prior to challenge inoculation. Otherwise no cross-protection occurred but the plants became systemically co-infected with the protector and challenger isolate. This was shown by challenge-inoculation of the upper leaves a day or two before they became systemically infected with the protector isolate [11 or 12 days postinoculation (dpi); absence of protector virus verified by ELISA]. Also, in the experiments where cross-protection was overcome, and not circumvented as in the example described here, the plants became systemically co-infected with both the protector and challenger isolate (Table 4).

Distribution of isolates Sab, M, and B11 (and B11-dag, discussed below) was tested in the systemically infected leaves using tissue prints of leaf cross-sections (Karyeija et al. 2000). The prints on nitrocellulose membranes (NCM) were observed under microscope. The leaf lamina were found to be thoroughly infected and no difference in virus distribution was observed between the isolates (Fig. 4). Therefore, the ability of isolate Sab to overcome M (Table 3B), or isolate B11 to overcome Sab and U (Table 3A and D) could not be explained with some sectors of the challenge-inoculated leaves being uninfected with the protector isolate. Furthermore, these data showed that the large differences in the levels to which these isolates accumulated in the leaves (Fig. 5) were due to differences in virus accumulation in infected cells and not caused by gross differences in viral cell-to-cell movement. Finally, it is important to note that all PVA isolates and chimeric viruses (discussed below) used in this study infected tobacco plants systemically with a similar speed, which also indicated that differences in virus accumulation were not associated with differences in viral movement.
All together, results indicated that cross-protection was effective only at the initiation of infection. The potato strains provided only weak cross-protection against the tobacco strain, whereas the tobacco strain provided efficient cross-protection against potato strains in tobacco plants. The tamarillo strain TamMV showed cross-protection phenotypes mostly resembling those of the potato strains.

\section{CP-sequence relatedness and cross-protection.}

Cross-protection between virus isolates is expected to depend on their relatedness (Matthews 1991) and the CP has been indicated as a key factor in cross-protection (Beachy 1999; Lu et al. 1998); therefore, it was hypothesized that the CP-sequence relatedness (Rajamäki et al. 1998) would explain cross-protection between PVA isolates. This presumption appeared to be true in some PVA strain combinations. The distantly related tobacco (B11) and tamarillo (TamMV) strains (Table 1) showed no cross-protection against each other (Table $3 \mathrm{C}$ and D; Fig. 3). On the other hand, cross-protection was observed between the slightly closer related strains $\mathrm{Sab}$ and TamMV (Table 3A and B). Therefore, a CP sequence identity higher than approximately $88 \%$ at the nucleotide sequence level, or higher than approximately $94 \%$ at the amino acid sequence level (Table 1) seems to be required for cross-protection between PVA isolates in tobacco plants. Otherwise, the cross-protection abilities were not simply predictable from the $\mathrm{CP}$ sequence relatedness. For example, isolate Sab provided $100 \%$ protection against other potato strains (Can, M, and U), but only partial cross-protection against the tobacco strain (isolates Ali, B11, Dat, and 716/12) (Fig. 2). These results were unexpected because the CP sequences between Sab and other potato strains are no more similar than those between $\mathrm{Sab}$ and the tobacco strain isolates (Table 1) (Rajamäki et al. 1998). It was also unexpected that, in the reciprocal tests, $M$ provided no cross-protection against Sab (Table 3B).

\section{The CP-encoding region is important for cross-protection.}

The tobacco strain isolates of PVA were superior in crossprotection against the potato strains, regardless of whether used as protectors or challengers. The tobacco strain isolates have closely related $\mathrm{CP}$ and $3^{\prime}$-nontranslated region (NTR) sequences and accumulate to very high titers in tobacco plants (Fig. 5), and are thereby distinguishable from the potato strains and TamMV (Rajamäki et al. 1998; Valkonen et al. 1995). The high accumulation in tobacco plants is caused by a substitution Gly $\rightarrow$ Ser at the position 7 of the PVA CP (Andrejeva et al. 1999). The next question, therefore, was whether the CP-encoding region or the $3^{\prime}$-NTR was important for the superior cross-protection phenotype of the tobacco strain and whether high virus accumulation was dispensable for it.

Table 1. Percentage of nucleotide (lower diagonal) and deduced amino acid sequence identities (above diagonal) between the coat protein-encoding sequences of isolates of Potato virus A

\begin{tabular}{|c|c|c|c|c|c|c|c|c|c|}
\hline \multirow[b]{2}{*}{ Strains } & \multicolumn{4}{|c|}{ Tobacco strain isolates } & \multicolumn{4}{|c|}{ Potato strains } & \multirow[b]{2}{*}{ TamMV $^{\mathrm{a}}$} \\
\hline & B11 & $716 / 12$ & Ali & Dat & Can & M & Sab & $\mathbf{U}$ & \\
\hline \multicolumn{10}{|l|}{ Tobacco } \\
\hline B11 & $\ldots$ & 98.9 & 98.9 & 99.3 & 96.7 & 95.9 & 95.5 & 95.9 & 93.7 \\
\hline $716 / 12$ & 99.4 & & 98.5 & 99.6 & 97.8 & 97.0 & 96.3 & 97.0 & 94.0 \\
\hline Ali & 99.1 & 99.0 & & 98.9 & 96.3 & 95.5 & 94.8 & 95.5 & 93.3 \\
\hline Dat & 99.5 & 99.6 & 99.1 & $\ldots$ & 97.4 & 96.7 & 95.9 & 96.7 & 93.7 \\
\hline \multicolumn{10}{|l|}{ Potato } \\
\hline Can & 96.7 & 97.3 & 96.3 & 96.9 & 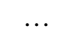 & 98.5 & 97.8 & 97.0 & 94.8 \\
\hline M & 96.7 & 97.3 & 96.3 & 96.9 & 99.3 & $\ldots$ & 97.8 & 96.3 & 95.1 \\
\hline Sab & 96.4 & 97.0 & 96.0 & 96.7 & 98.5 & 98.8 & & 95.9 & 94.8 \\
\hline $\mathrm{U}$ & 97.3 & 97.7 & 96.9 & 97.5 & 96.4 & 96.4 & 96.7 & $\ldots$ & 92.9 \\
\hline TamMV & 87.1 & 87.4 & 86.9 & 87.3 & 88.3 & 88.6 & 88.8 & 87.3 & $\ldots$ \\
\hline
\end{tabular}

\footnotetext{
${ }^{\mathrm{a}}$ Tamarillo strain.
} 
Two PVA chimera were used. In one of them, the CP-encoding sequence of an infectious cDNA of isolate B11 (tobacco strain isolate) was replaced with the corresponding sequence of the potato strain $\mathrm{U}$ (chimeric virus $\mathrm{B} 11-\mathrm{U}_{\mathrm{CP}}$; Fig. 1). In the other construct, two adjacent nucleotides were substituted to introduce a novel NaeI restriction site and a single amino acid substitution (Ser7Gly) to the CP N-terminus of B11 (B11-dag; Fig. 1). B11$\mathrm{U}_{\mathrm{CP}}$ and B11-dag accumulated to similar low titers in tobacco plants (Table 2; Fig. 5). However, cross-protection phenotypes of B11- $\mathrm{U}_{\mathrm{CP}}$ and B11-dag were completely different. B11- $\mathrm{U}_{\mathrm{CP}}$ provided no cross-protection against B11, whereas B11-dag provided $100 \%$ cross-protection against B11 (Table 3E). Thus, high sequence similarity between the CP-encoding region of the protector and challenger was important for cross-protection. Indeed, the $\mathrm{CP}$-encoding region rather than the $3^{\prime}$-NTR was decisive for cross-protection since B11- $\mathrm{U}_{\mathrm{CP}}$ and B11-dag contain the same 3'-NTR sequence. Additional evidence that the CP-encoding sequence is important in cross-protection was obtained in other experiments, in which Sab provided high cross-protection against $\mathrm{B} 11-\mathrm{U}_{\mathrm{CP}}$ (Table 3E) and $\mathrm{U}$ (Table 3A), but only low cross-protection against B11 (Table 3A), and TamMV provided similarly low cross-protection against B11- $\mathrm{U}_{\mathrm{CP}}$ and $\mathrm{U}$ (Table 3E) but no cross-protection against B11 (Table 3D).

The Sab-infected plants were highly cross-protected (100\%) against B11-dag (Table 3E), but significantly lower levels (ANOVA, $p<0.05)$ of cross-protection $(42 \%)$ were observed against B11 (Table 3A), despite only differences of only $2 \mathrm{nt}$ between B11-dag and B11. Therefore, an increased level of accumulation appears to provide the challenger virus with a higher ability to overcome cross-protection.

The aforementioned experiments (Fig. 2; Table 3A through E) suggest that, of two PVA strains accumulating to similar

Table 2. Detection of isolates of Potato virus $A^{\mathrm{a}}$ with the anti-coat protein monoclonal antibodies (MAbs) $58 / 0$ and $58 / 6$ by double antibody sandwich enzyme-linked immunosorbent assay

\begin{tabular}{|c|c|c|}
\hline Virus & MAb 58/0 & MAb 58/6 \\
\hline \multicolumn{3}{|l|}{ Tobacco strain isolates } \\
\hline Ali & $2.43(0.02)$ & 0 \\
\hline B11 & $1.85(0.05)$ & 0 \\
\hline Dat & $1.91(0.00)$ & 0 \\
\hline $716 / 12$ & $3.06(0.01)$ & $0.08(0.00)$ \\
\hline \multicolumn{3}{|l|}{ Potato strains } \\
\hline Can & $0.91(0.13)$ & $0.35(0.03)$ \\
\hline M & $0.45(0.03)$ & $0.38(0.02)$ \\
\hline $\mathrm{Sab}$ & 0 & $0.59(0.06)$ \\
\hline $\mathrm{U}$ & $0.70(0.00)$ & $0.21(0.00)$ \\
\hline \multicolumn{3}{|l|}{ Tamarillo strain } \\
\hline TamMV & $1.34(0.29)$ & 0 \\
\hline \multicolumn{3}{|l|}{ PVA chimera } \\
\hline $\mathrm{B} 11-\mathrm{U}_{\mathrm{HC}}$ & $2.77(0.07)$ & 0 \\
\hline $\mathrm{B} 11-\mathrm{M}_{6 \mathrm{KVPg}}$ & $1.01(0.05)$ & 0 \\
\hline B11-dag & $1.22(0.07)$ & 0 \\
\hline $\mathrm{B} 11-\mathrm{U}_{\mathrm{HC}} \mathrm{M}_{6 \mathrm{KVPg}} \mathrm{U}_{\mathrm{CP}}$ & $1.42(0.10)$ & $1.31(0.09)$ \\
\hline $\mathrm{B} 11-\mathrm{M}_{6 \mathrm{KVPg}} \mathrm{U}_{\mathrm{CP}}$ & $0.77(0.04)$ & $0.12(0.03)$ \\
\hline $\mathrm{B} 11-\mathrm{U}_{\mathrm{CP}}$ & $1.11(0.08)$ & $0.32(0.03)$ \\
\hline \multicolumn{3}{|l|}{ Controls } \\
\hline \multicolumn{3}{|l|}{ Purified virions } \\
\hline B11 (200 ng) & $2.43(0.00)$ & 0 \\
\hline $\mathrm{U}(200 \mathrm{ng})$ & $2.55(0.00)$ & $2.32(0.00)$ \\
\hline Healthy plants & 0 & 0 \\
\hline
\end{tabular}

\footnotetext{
${ }^{a}$ Mean absorbance value $\left(\mathrm{A}_{405}\right)$ for three plants recorded at 45 min after adding the substrate at room temperature (standard deviation in parentheses). All isolates were inoculated in the same experiment. Plants were grown at $17^{\circ} \mathrm{C}$ day, $19^{\circ} \mathrm{C}$ night in a growth chamber. Systemically infected leaves were tested at 14 days post inoculation. Zero indicates that absorbance value was the same or lower than the mean for the six sample buffer wells $\left(\mathrm{A}_{405}=0.06, \mathrm{SD} 0.00\right)$ used as negative controls in each plate. This background absorbance value has been subtracted from the other sample absorbance values.
}

levels, the strain with a more closely related CP-encoding region to the challenger virus will provide stronger cross-protection. On the other hand, of two PVA strains with a similar genetic distance to the protector isolate, the strain accumulating in higher titers will be more likely to overcome cross-protection. Consequently, the combination of the two factors (level of virus accumulation and CP sequence relatedness) appears to constitute an important part of the cross-protection phenotype.

\section{Cross-protection against viral RNA.}

Our data indicated that the $\mathrm{CP}$-encoding region was very important for cross-protection between PVA isolates. If crossprotection in PVA was similar to the inhibition of virion disassembly described for TMV, inoculation with viral RNA should overcome cross-protection (Beachy 1999; Lu et al. 1998), which was tested.

Using sap extracted from PVA-infected leaves for inoculation, infection is most likely initiated by virions (i.e., viral RNA protected by the $\mathrm{CP}$ at entry to the cells). Mechanical inoculation with PVA RNA using a similar method results in only a very low percentage of infected tobacco plants unless microgram quantities of RNA are used (J. Valkonen, unpublished data). In contrast, infection is efficient with viral RNA using the handheld particle bombardment device for inoculation (Kekarainen and Valkonen 2000). This method was used to inoculate naked, $\mathrm{m}^{7} \mathrm{G}$-capped in vitro RNA transcripts of $\mathrm{B} 11-\mathrm{U}_{\mathrm{CP}}$ to leaves previously infected with B11. In three experiments, each including $10 \mathrm{~B} 11$-infected and 10 healthy control plants, B11 provided $100 \%$ protection against $\mathrm{B} 11-\mathrm{U}_{\mathrm{CP}}$ RNA (Fig. 3). Inoculated leaf areas were excised from several leaves and tested for B11- $\mathrm{U}_{\mathrm{CP}}$ by reverse-transcriptase polymerase chain reaction (RT-PCR), but the results were negative (Fig. 3). In contrast, 16 of the total of 30 control plants were systemically infected by $\mathrm{B} 11-\mathrm{U}_{\mathrm{CP}}$. It was not surprising that less than $100 \%$ of these control plants were infected, because they were bigger and less susceptible at the time of inoculation

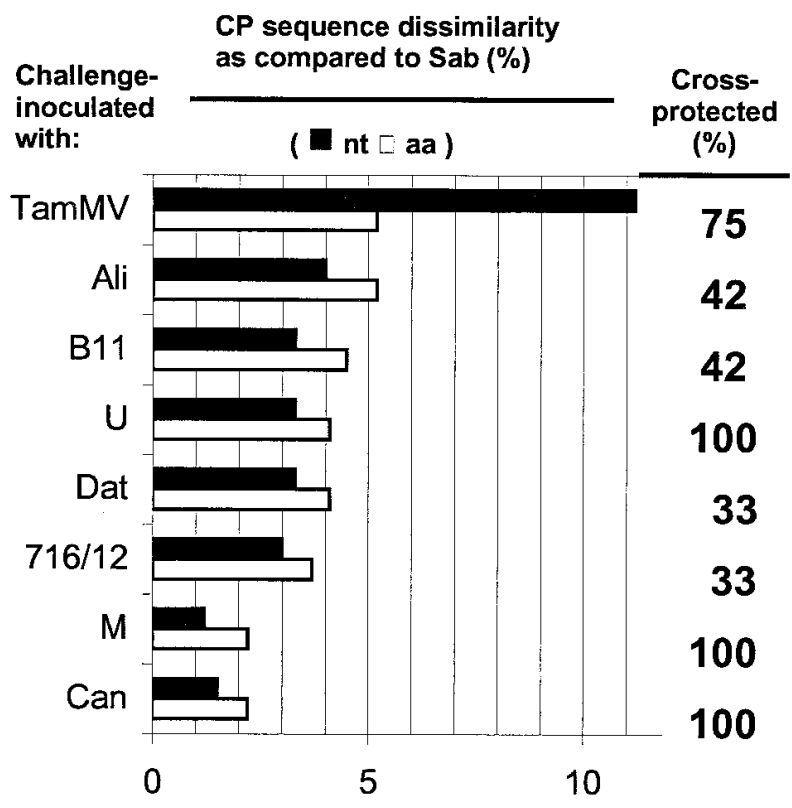

Fig. 2. The ability of Potato virus A (PVA), isolate Sab to cross-protect against other PVA isolates in tobacco plants is not predictable simply based on the coat protein $(\mathrm{CP})$ sequence identity between the protector and challenger isolate. Plants were systemically infected with the protector isolate at the time of challenge inoculation. The percentage of plants cross-protected is indicated (a total of 12 plants in three experiments). All control plants (not infected with Sab prior to inoculation with the challenger isolates) were infected. 
than the small seedlings usually inoculated (Kekarainen and Valkonen 2000). However, considering the fact that more than $50 \%$ of controls became infected, whereas none of the protected plants became infected, it is concluded that inoculation with viral RNA did not overcome cross-protection.

Sab protected poorly against B11 inoculated in sap extracted from infected leaves (Table 3A); therefore, we tested crossprotection against B11 inoculated as naked, $\mathrm{m}^{7} \mathrm{G}$-capped in vitro RNA transcripts. In the two experiments including 10 plants, no Sab-infected plant was infected with B11, whereas all control plants were systemically infected with B11. These data provide additional evidence that inoculation with viral RNA does not overcome cross-protection, including cases where cross-protection to inoculation with virions is not particularly strong.

\section{Significance of the $6 \mathrm{~K} 2$ - viral genome-linked protein region and $\mathrm{HCpro}$ in cross-protection.}

Two additional genomic regions were relevant to be tested for their role in cross-protection. One of them encodes for the viral genome-linked protein $(\mathrm{VPg})$ that is covalently bound to the $5^{\prime}$ end of viral RNA (Fig. 1) in virions of PVA (Oruetxebarria et al. 2001). It may protect the $5^{\prime}$ end of viral RNA against degradation and may be involved in initiation of infection (Hari 1981; Oruetxebarria et al. 2001; Riechmann et al. 1989; Shukla et al. 1994). Some amino acid substitutions in the VPg cause significant host-dependent defects in the long distance movement of PVA (Hämäläinen et al. 2000; Rajamäki and Valkonen 1999, 2002), but none of these are known to affect the movement of PVA in tobacco plants. A genomic fragment $(1,208 \mathrm{nt})$ containing the $\mathrm{VPg}$-encoding region, the $6 \mathrm{~K} 2$ protein-encoding region, and a C-terminal portion of the $\mathrm{CI}$ protein-encoding region was replaced in the infectious cDNA of B11 with the corresponding region of isolate $M$ (B11$\mathrm{M}_{6 \mathrm{KVPg}}$; Fig. 1) (Rajamäki and Valkonen 1999). The sequence replacement introduced three amino acid substitutions to the VPg and one amino acid substitution to the $6 \mathrm{~K} 2$ protein (Fig. $1)$. The accumulation of $\mathrm{B} 11-\mathrm{M}_{6 \mathrm{KVPg}}$ was reduced compared with B11, but was 10-fold enhanced compared with M (Fig. 5). Sab cross-protected poorly against B11- $\mathrm{M}_{6 \mathrm{KVPg}}$ (Table $3 \mathrm{~F}$ ) and B11 (Table 3A), in contrast to $\mathrm{M}$ (Table 3A). The crossprotection phenotype of $\mathrm{B} 11-\mathrm{M}_{6 \mathrm{KVPg}}$ was therefore quite similar to B11. In another chimeric virus $\left(B 11-\mathrm{M}_{6 \mathrm{KVPg}} \mathrm{U}_{\mathrm{CP}}\right)$, the $\mathrm{CP}-$ encoding region of $\mathrm{B} 11-\mathrm{M}_{6 \mathrm{KVPg}}$ was replaced with that of $\mathrm{U}$ (Fig. 1). The cross-protection phenotype of B11- $\mathrm{M}_{6 \mathrm{KVg}} \mathrm{U}_{\mathrm{CP}}$ was most similar to that of B11- $\mathrm{U}_{\mathrm{CP}}$. For example, Sab provided similar levels of protection against the two chimeras that, in turn, provided no cross-protection against B11 (Table $3 \mathrm{E}$ and $\mathrm{F}$ ) in contrast to $\mathrm{B} 11-\mathrm{M}_{6 \mathrm{KVPg}}$, which provided $100 \%$ protection against B11 (Table $3 \mathrm{~F}$ ). These data indicated that the $6 \mathrm{~K} 2-\mathrm{VPg}$ region had no major role in cross-protection, but, as found before, the $\mathrm{CP}$-encoding region had a predominant effect. Data also indicated that both the 6K2-VPg-encoding region of $\mathrm{M}$ and the $\mathrm{CP}$-encoding region of $\mathrm{U}$ reduced virus titers compared with isolate B11. The effect of the two regions was cumulative (Fig. 5).

The other region of interest in cross-protection encodes for the HCpro that stimulates genome amplification (Atreya et al. 1992) and can suppress PTGS (Anandalakshmi et al. 1998; Brigneti et al. 1998; Dalmay et al. 2000a; Kasschau and Carrington 1998). The mutations introduced into the HCpro of $\mathrm{B} 11$ in the construct $\mathrm{B} 11-\mathrm{U}_{\mathrm{HC}}$ (Fig. 1) made it resemble the HCpro of strain U (Andrejeva et al. 1999). The cross-protection phenotype of B11- $\mathrm{U}_{\mathrm{HC}}$ was different from B11 because cross-protection in plants infected with $\mathrm{Sab}$ was overcome more frequently with $\mathrm{B} 11-\mathrm{U}_{\mathrm{HC}}(17 \%$ plants protected; Table $3 \mathrm{G})$ than with B11 (42\%; Table 3A) (ANOVA, $p<0.05)$. The amino acid substitutions within the HCpro, 6K2-VPg, and $\mathrm{CP}$ domains were combined into a new chimeric virus designated as $\mathrm{B} 11-\mathrm{U}_{\mathrm{HC}} \mathrm{M}_{6 \mathrm{KVPg}} \mathrm{U}_{\mathrm{CP}}$ (Fig. 1). The accumulation of this virus was increased compared with $\mathrm{B} 11-\mathrm{M}_{6 \mathrm{KVPg}} \mathrm{U}_{\mathrm{CP}}, \mathrm{B} 11-\mathrm{M}_{6 \mathrm{KVPg}}$, and B11- $\mathrm{U}_{\mathrm{CP}}$ (Fig. 5). The chimera B11- $\mathrm{U}_{\mathrm{HC}} \mathrm{M}_{6 \mathrm{KVPg}} \mathrm{U}_{\mathrm{CP}}$ had an increased capability to overcome cross-protection in plants infected with Sab (25\% of plants protected; Table 3G), compared with $\mathrm{B} 11-\mathrm{M}_{6 \mathrm{KVPg}} \mathrm{U}_{\mathrm{CP}}$ (83\% of plants protected) (Table $3 F)(p<0.05)$. Thus, the HCpro had an influence on the crossprotection phenotype.

Neither B11- $\mathrm{U}_{\mathrm{HC}}$ nor any other B11-based virus chimera could overcome cross-protection conferred by B11 (data not shown).

\section{DISCUSSION}

This study shows that cross-protection between the isolates of PVA involves reciprocal cross-protection of varying degrees of completeness and unilateral cross-protection, as previously found (e.g., with strains of Tobacco streak ilarvirus, a member of the family Bromoviridae, in tobacco plants) (Fulton 1978). It is presumed that cross-protection is correlated with genetic (phylogenetic) relatedness (Bos 1999; Fraser 1998; Gonsalves

Table 3. Reciprocal cross-protection tests using isolates and chimera of Potato virus A

\begin{tabular}{|c|c|c|}
\hline Protector $^{\mathrm{a}}$ & Challenger & Plants cross-protected $(\%)^{b}$ \\
\hline \multicolumn{3}{|l|}{ A. } \\
\hline $\mathrm{Sab}$ & Can & $100^{\mathrm{c}}$ \\
\hline Sab & M & $100^{\mathrm{c}}$ \\
\hline $\mathrm{Sab}$ & $\mathrm{U}$ & $100^{\mathrm{c}}$ \\
\hline Sab & TamMV & $75^{\mathrm{c}}$ \\
\hline Sab & Ali & $42^{\mathrm{c}}$ \\
\hline Sab & B11 & $42^{\mathrm{c}}$ \\
\hline Sab & Dat & $33^{\mathrm{c}}$ \\
\hline $\mathrm{Sab}$ & $716 / 12$ & $33^{\mathrm{c}}$ \\
\hline \multicolumn{3}{|l|}{ B. } \\
\hline Ali & Sab & 100 \\
\hline B11 & Sab & 100 \\
\hline TamMV & Sab & 75 \\
\hline M & $\mathrm{Sab}$ & 0 \\
\hline \multicolumn{3}{|l|}{ C. } \\
\hline B11 & Can & 100 \\
\hline B11 & Sab & 100 \\
\hline B11 & $\mathrm{U}$ & 100 \\
\hline B11 & TamMV & 0 \\
\hline \multicolumn{3}{|l|}{ D. } \\
\hline $\mathrm{U}$ & B11 & 0 \\
\hline TamMV & B11 & 0 \\
\hline \multicolumn{3}{|l|}{ E. } \\
\hline $\mathrm{B} 11-\mathrm{U}_{\mathrm{CP}}$ & B11 & 0 \\
\hline B11-dag & B11 & 100 \\
\hline $\mathrm{Sab}$ & $\mathrm{B} 11-\mathrm{U}_{\mathrm{CP}}$ & 92 \\
\hline $\mathrm{Sab}$ & B11-dag & 100 \\
\hline TamMV & $\mathrm{U}$ & 25 \\
\hline TamMV & $\mathrm{B} 11-\mathrm{U}_{\mathrm{CP}}$ & 25 \\
\hline \multicolumn{3}{|l|}{ F. } \\
\hline Sab & $\mathrm{B} 11-\mathrm{M}_{6 \mathrm{KVPg}}$ & 33 \\
\hline $\mathrm{Sab}$ & $\mathrm{B} 11-\mathrm{M}_{6 \mathrm{KVPg}} \mathrm{U}_{\mathrm{CP}}$ & 83 \\
\hline $\mathrm{B} 11-\mathrm{M}_{6 \mathrm{KVPg}} \mathrm{U}_{\mathrm{CP}}$ & B11 & 0 \\
\hline $\mathrm{B} 11-\mathrm{M}_{6 \mathrm{KVPg}}$ & B11 & 100 \\
\hline \multicolumn{3}{|l|}{ G. } \\
\hline Sab & $\mathrm{B} 11-\mathrm{U}_{\mathrm{HC}}$ & 17 \\
\hline Sab & $\mathrm{B} 11-\mathrm{U}_{\mathrm{HC}} \mathrm{M}_{6 \mathrm{KVPg}} \mathrm{U}_{\mathrm{CP}}$ & 25 \\
\hline
\end{tabular}

${ }^{\text {a }}$ Figure 1 and its caption provide information about the virus chimeras.

${ }^{\mathrm{b}}$ Mean from three experiments, each including four tobacco plants. Systemic infection with the challenger virus was determined by double antibody sandwich enzyme-linked immunosorbent assay using the appropriate monoclonal antibody or by reverse-transcriptase polymerase chain reaction followed by restriction analysis or sequencing of the product.

${ }^{\mathrm{c}}$ Same result shown in Figure 2. 
1998; Matthews 1991). Accordingly, the cross-protection data of this study suggest that the tamarillo strain of PVA (TamMV) is more closely related to the potato strains of PVA than the tobacco strain of PVA, because some cross-protection was found between the former in contrast to the latter. This finding is
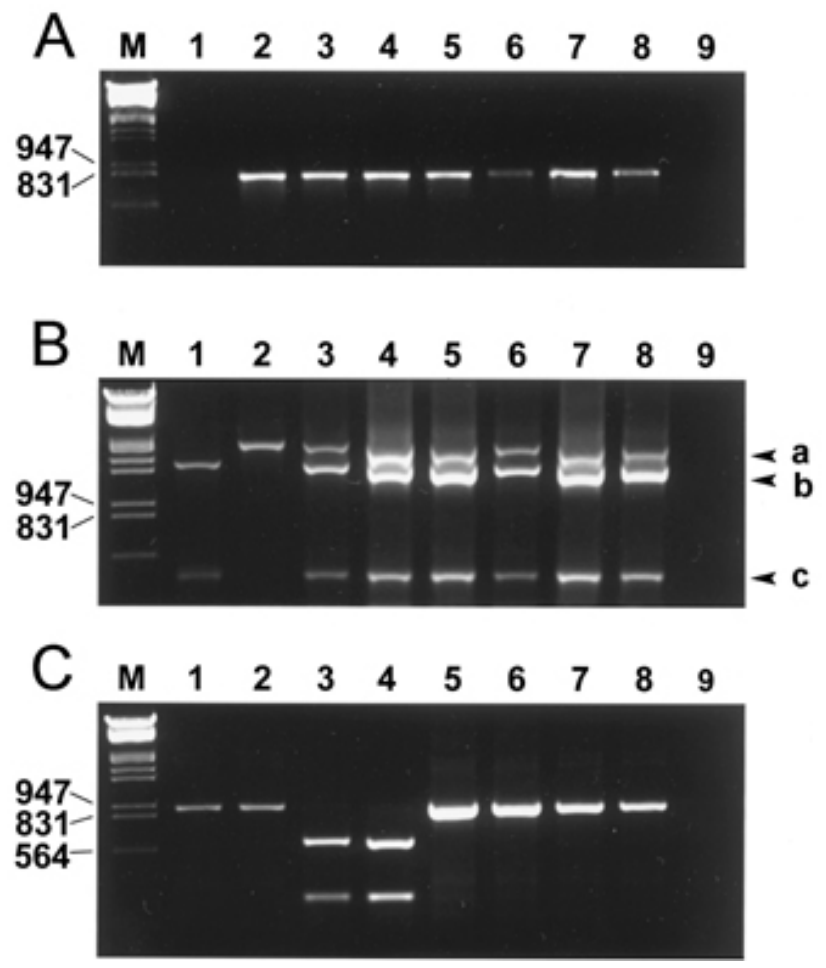

Fig. 3. Detection of the protector and challenger isolates and a chimera of Potato virus $A$ by reverse-transcriptase polymerase chain reaction at 16 days post challenge-inoculation. A, Isolate B11 does not cross-protect against isolate TamMV. The plants were systemically infected with the protector isolate B11 prior to challenge inoculation with TamMV. Virus detection was carried out on the upper noninoculated leaves using TamMV-specific primers designed for the CI-encoding region. A product of the expected size was observed in all challenge-inoculated plants (seven plants, lanes 2 through 8 ). No product was detected in plants infected only with B11 (lane 1) or in healthy plants (lane 9). M, DNA ( $\lambda$ ) size marker with the size (bp) of the relevant markers indicated. B, Isolate TamMV does not cross-protect against isolate B11. The plants were systemically infected with the protector isolate TamMV prior to challenge inoculation with B11. Virus detection was carried out on the upper noninoculated leaves using primers designed for the CI-encoding region and that amplify both B11 and TamMV. The product was tested by restriction with BamHI, which cleaves the product of B11 once (lane 1) but has no restriction site in the product derived from TamMV (lane 2). In all challenge-inoculated plants (lanes 3 through 8), the uncleaved product of TamMV (a) and the cleavage products of B11 (b and c) were detected. No product was detected in healthy plants (lane 9). C, Cross-protection is not overcome by inoculation with viral RNA. The plants were systemically infected with the protector isolate $\mathrm{B} 11$ prior to challenge inoculation with the infectious RNA of B11- $\mathrm{U}_{\mathrm{CP}}$ (inoculated by microprojectile bombardment). Virus detection was carried out on inoculated and upper noninoculated leaves using primers designed for the coat protein (CP)-encoding region and that amplify both $\mathrm{B} 11$ and $\mathrm{B} 11-\mathrm{U}_{\mathrm{CP}}\left(\mathrm{B} 11-\mathrm{U}_{\mathrm{CP}}\right.$ is a chimera of $\mathrm{B} 11$ carrying the $\mathrm{CP}$ gene of isolate $\mathrm{U}$ ). The product was tested by restriction with $X m n \mathrm{I}$, which cleaves the product of $\mathrm{B} 11-\mathrm{U}_{\mathrm{CP}}$ once but has no restriction site in the product derived from B11. Lanes 1 and 2, detection of B11 in an inoculated and a systemically infected leaf, respectively, of a control plant not infected with B11- $\mathrm{U}_{\mathrm{CP}}$. Lane 3 and 4 , detection of $\mathrm{B} 11-\mathrm{U}_{\mathrm{CP}}$ in an inoculated and a systemically infected leaf, respectively, of a control plant not infected with B11. Lanes 5 and 6 , two sample pools, each containing five inoculated leaf areas excised from B11-infected leaves challenge-inoculated with B11- $\mathrm{U}_{\mathrm{CP}}$; only B11 and no B11- $\mathrm{U}_{\mathrm{CP}}$ is observed. Lanes 7 and 8 , two sample pools, each containing five leaf discs collected from upper noninoculated leaves of plants challenge-inoculated with B11- $\mathrm{U}_{\mathrm{CP}}$; only B11 and no B11- $U_{\mathrm{CP}}$ is observed. No product was detected in healthy plants (lane 9). consistent with the phylogenetic relatedness (Kekarainen et al. 1999; Rajamäki et al. 1998). However, the tobacco strain of PVA (isolates propagated in Nicotiana spp. since their isolation from potato plants over 20 years ago) was superior in cross-protecting and overcoming cross-protection compared with the strains maintained in potato, regardless of the relative genetic relatedness. The tobacco strain of PVA is defective for systemic movement in potato plants (Andrejeva et al. 1999; Hämäläinen et al. 2000; Rajamäki et al. 1998; Rajamäki and Valkonen 2002); therefore, cross-protection in potato could not be tested. For this reason, our data are only provisional in suggesting that, as a part of a host adaptation process, the virus may gain a higher ability to cross-protect against other, less adapted strains in the host. This possibility also is suggested by previous studies showing that cross-protection between virus isolates may be host-dependent (Fraser 1998).

After determining the cross-protection phenotypes of several PVA isolates and observing significant differences, we proceeded to map for viral genomic regions important for these differences using PVA mutants and chimera. The PVA isolates, mutants, and chimera spread systemically with a similar speed in the tobacco plants and were similarly distributed in the systemically infected leaves (those to be challenge inoculated), which excluded differences in virus movement (Dolja et al. 1994) as a factor explaining the differences in cross-protections phenotypes. The $\mathrm{CP}$-encoding region had a profound effect on the cross-protection phenotype. Accumulation to higher titers, which is determined by Ser at position 7 of the CP (Andrejeva et al. 1999), and a more distant genetic relatedness to the protector virus, as determined by the CP-encoding region, made the challenger virus more likely to overcome cross-protection. Thus, the two factors determined by the $\mathrm{CP}$-encoding region are largely responsible for the cross-protection phenotype.

The cross-protected leaves apparently were uninfected with the challenger isolates, which indicated inhibition of an initial stage of infection. Furthermore, because the CP-encoding region was important for the PVA cross-protection, re-encapsidation of PVA virions was anticipated as the mechanism of crossprotection. In the TMV reencapsidation model, a few 5'-terminal CP subunits are released from the virion of the challenger virus at infection, which exposes a small number of nucleotides that are subsequently recoated by the protecting $\mathrm{CP}$ ( $\mathrm{Lu}$ et al. 1998). Hence, initiation of infection with the challenger virus is prohibited. The model requires efficient CP selfassociation for cross-protection and predicts that unencapsidated viral RNA can overcome cross-protection (Beachy 1999; Lu et al. 1998; Sherwood and Fulton 1982). The CP of PVA forms virion-like particles in the absence of viral RNA and, thus, apparently self-interacts (Rajamäki et al. 1998; J. Valkonen, unpublished data), and it binds RNA (Merits et al. 1998). The virions and the $\mathrm{CP}$ of the tobacco strain (B11) of PVA are more stable than those of the potato strains ( $M$ and $U$ ), as studied previously (Valkonen et al. 1995). Furthermore, virions of isolate B11 form very long end-to-end attached filaments, in contrast to the virions of strains $\mathrm{M}, \mathrm{Sab}, \mathrm{U}$, and $\mathrm{B} 11-\mathrm{U}_{\mathrm{CP}}$ (J. Valkonen, unpublished data). These data imply significant differences between the CPs of the tobacco and potato strains, and the differences appear to be correlated with the differences in cross-protection abilities. However, our experiments showed that cross-protection was effective against inoculation with PVA RNA, which was contrary to the expected outcome of cross-protection based on inhibition of virion disassembly. Therefore, the reencapsidation hypothesis was not supported with these data.

The other mechanism implicated in cross-protection is PTGS, because viruses which normally coinfect a host without interference do cross-protect against each other when engi- 
neered to carry identical RNA sequences (Ratcliff et al. 1999). Also, host RdRps are involved in PTGS, and an RdRp is required in TMV-infected tobacco leaves ( $N$. tabacum) for the development of virus-free green islands (Xie et al. 2001) that are cross-protected against TMV (Matthews 1991). Leaves of N. benthamiana systemically infected with PVA isolates B11 (J. Valkonen, M.-L. Rajamäki, and T. Kekarainen, unpublished data) and TamMV (Moore et al. 2001) develop green islands. In $N$. benthamiana plants transformed with the CP-encoding region of TamMV, the green islands resemble those observed in nontransformed plants and contain highly reduced amounts of TamMV, in contrast to the surrounding chlorotic tissue (Moore et al. 2001). The results of Xie and associates (2001) and Moore and associates (2001) imply that PTGS may operate in the green islands and that distinctiveness of the pattern of mosaic symptoms (chlorotic versus green areas) in leaves depends on how strongly or uniformly PTGS is induced. In $\mathrm{Ni}$ candra physaloides, PVA isolates $\mathrm{M}, \mathrm{U}$, and $\mathrm{B} 11$ induce pronounced patterns of dark green and chlorotic leaf tissues ( $\mathrm{J}$. Valkonen, M.-L. Rajamäki, and T. Kekarainen, unpublished data), which resemble those caused by another potyvirus, $\mathrm{Wa}$ termelon mosaic virus (WMV), in pumpkin leaves. Similar to the TMV-induced mosaic pattern in tobacco leaves, the chlorotic areas of pumpkin leaves contain high virus titers, whereas the dark areas are free of WMV (Suzuki et al. 1989). Thus, potyvirus infections may activate PTGS.

Our data show that amino acid substitutions in the HCpro, the potyviral suppressor of PTGS (Anandalakshmi et al. 1998; Brigneti et al. 1998; Kasschau and Carrington 1998), increases the accumulation of PVA (Fig. 5) and enhances an ability to overcome cross-protection (Table $3 \mathrm{~A}$ and $\mathrm{G}$ ). The substitutions at position 153 and 330 of the PVA HCpro (B11-U $\mathrm{HC}_{\mathrm{HC}}$ (Fig. 1) map to areas where mutations in the HCpro of Tobacco etch virus (TEV) (mutant A20) debilitate genome amplification and gene silencing suppression abilities (Kasschau and Carrington 2001). All together, these data may infer that infection with PVA activates PTGS in tobacco plants, which in turn may be involved in PVA cross-protection. The finding is important because, in contrast to Nicotiana benthamiana, tobacco leaves infected with PVA develop only mild mosaic symptoms, and no green islands that could visually reveal PTGS activation are observed. Direct evidence for support of this hypothesis may be difficult to obtain, because systemic infection of the plants with a HCpro-producing protector virus probably would prevent (Mallory et al. 2001) production and detection of the short (21 to $25 \mathrm{nt})$ dsRNAs associated with PTGS (Elbashir et al. 2001; Hamilton and Baulcombe 1999).

The role of the CP-encoding region in the PVA cross-protection is intriguing and requires further study. We postulate a working hypothesis predicting that its role is associated with protection of the viral $3^{\prime}$ terminal sequences from degradation during replication. A previously presented theory predicts that titers of viruses in host plants are determined by an equilibrium between the antagonistic forces constituted by the host-driven PTGS and the virus-enforced suppression of PTGS (Mourrain et al. 2000; Ratcliff et al. 1999; Voinnet et al. 1999). Although the theory describes how the level of virus accumulation may be determined, it does not explain how RNA viruses protect themselves against the RNA degradation mechanism. There must be other mechanisms besides PTGS suppression to circumvent degradation of viral RNA during replication in the cytoplasm. Furthermore, if higher virus accumulation was solely achieved with a higher ability to suppress PTGS, accumulation of the protector virus should increase in the doubly-infected plants where the challenger virus causes additional suppression of PTGS. However, we found that the titer of Sab was not affected by any B11-based chimera (Table 4).
We speculate that a putative host-encoded RNA-degrading complex $(\mathrm{RDgC})$ competes with the putative viral replication complex (RC) for binding sites at the 3 '-end of the potyvirus $\mathrm{RNA}$, the $\mathrm{CP}$ or the $\mathrm{RC}$ and ribosomes prevent $\mathrm{RDgC}$ from recognizing or acting on viral RNA, and as yet unknown structural features of the $\mathrm{CP}$ or the $\mathrm{CP}$-encoding RNA are important for the protective function. This speculative model is suggested by many pieces of evidence. (i) The 3 '-part of the CPencoding sequence and the $3^{\prime}$-NTR possess cis-acting elements and RNA conformations necessary for genome amplification (Haldeman-Cahill et al. 1998; Mahajan et al. 1996), which makes their protection crucial for the virus. (ii) The host RdRp interacts with sequences close to the RNA 3' end (English et al. 1996; Goodwin et al. 1996). (iii) Studies on Papaya ringspot potyvirus (PRSV) chimeras in papaya plants transformed with the CP-encoding region of PRSV indicate that PTGS is targeted to the $3^{\prime}$ region of the CP transgene (Chiang et al. 2001). (iv) Known interactions between the potyviral and host proteins (Leonard et al. 2000; Wang et al. 2000) implicate homologous components in the putative RC (Mahajan et al. 1996; Shukla et al. 1994) and RDgC (Cogoni and Macino 2000; Waterhouse et al. 2001), which supports the possibility that $\mathrm{RC}$ and $\mathrm{RDgC}$ might compete for target RNA. (v) Nontranslatable TEV CP mRNA sequences are degraded faster and induce PTGS quicker than translatable sequences in transgenic tobacco plants (Lindbo et al. 1993), which suggests that the CP or the translation complex may protect mRNA against PTGS. (vi) Translation of the viral RNA over the 5'-half of the CP-encoding RNA sequence is required for efficient genome amplification, possibly because the translation process delivers nascent replication proteins to a site near the $3^{\prime}$ end of the genome (Mahajan et al. 1996). It would facilitate coupling of translation and replication (Novak and Kirkegaard 1994), which is compatible with the latest data suggesting that the VPg of poliovirus and potyviruses self-interact and replication may occur in a circular form (Oruetxebarria et al. 2001; Paul et al. 1998). These mechanisms would also serve for protecting the viral RNA ends against degradation. Other possible roles of the CP (e.g., binding to components of the RDgC and by such means inhibiting their binding or enzymatic activity) seem less likely because these mechanisms would cause a general suppression of PTGS in the host, which has not been reported for the potyviral CP. Many hypothetical mechanisms of cross-protection have been proposed (Matthews 1991) but none of them seem to be more compatible with our data and all have been proposed before PTGS was discovered.

This study represents, to our knowledge, the only case besides TMV where viral determinants of cross-protection have

Table 4. Titers of isolates of Potato virus A

\begin{tabular}{lcccc}
\hline Virus mixture & & & \multicolumn{2}{c}{ Virus amounts $(\mathbf{n g} / \mathbf{g})^{\mathbf{a}}$} \\
\hline Protector & Challenger & & Protector & Challenger \\
\hline Sab & $\mathrm{B} 11$ & & $1,200(510)$ & $7,300(330)$ \\
$\mathrm{Sab}$ & $\mathrm{B} 11-\mathrm{U}_{\mathrm{HC}}$ & & $1,300(270)$ & $7,000(540)$ \\
$\mathrm{Sab}$ & $\mathrm{B} 11-\mathrm{M}_{6 \mathrm{KVPg}}$ & & $1,400(220)$ & $4,100(980)$ \\
$\mathrm{Sab}$ & $\ldots$ & & $1,600(190)$ & $\ldots$ \\
\hline
\end{tabular}

${ }^{a}$ Virus amounts presented in ng of coat protein $(\mathrm{CP})$ antigen per $\mathrm{g}$ of leaf (standard deviation), as detected in the fourth leaf above the challengeinoculated leaf at 16 days after challenge-inoculation in six tobacco plants inoculated with each virus isolate combination. Isolate Sab was detected with monoclonal antibody (MAb) 58/6. Isolate B11 and the two chimeric viruses used for challenge-inoculation (all have identical CPs) were detected with MAb 58/0. Means of the amounts of Sab are not significantly different. Means for $\mathrm{B} 11$ and $\mathrm{B} 11-\mathrm{U}_{\mathrm{HC}}$ are significantly different from B11- $\mathrm{M}_{6 \mathrm{KVPg}}(p<0.05)$. Virus amounts per $\mathrm{g}$ of leaf are lower than those indicated in Figure 5, because here, the plants were 16 days older at sampling. 
been mapped to the viral genome. Two potyviral protein-encoding regions were found to be determinants of cross-protection. These findings represent the first step toward understanding the mechanism of potyviral cross-protection, a study field that so far has gained little attention.

\section{MATERIALS AND METHODS}

\section{Viruses, cloning, and sequencing.}

The PVA isolates used in this study have been described (Rajamäki et al. 1998; Valkonen et al. 1995). The complete sequences of the PVA isolates B11 (Puurand et al. 1994), Ali, U, and TamMV (Kekarainen et al. 1999) have been published. Sequences of the CP-encoding region and the $3^{\prime}$-NTR of isolates 716/12 (type isolate ATCC PV-266), Can, Dat, M, and Sab, and the 6K2- and VPg-encoding sequences of isolate $\mathrm{M}$ also have been determined (Rajamäki et al. 1998; Rajamäki and Valkonen 1999). The unpublished sequence of the $6 \mathrm{~K} 2-\mathrm{VPg}$ region of isolate $\mathrm{Sab}$ is available from the EMBL databank (accession number AJ277992).

PVA chimeras were constructed using the full-length infectious cDNA of PVA-B11 (Puurand et al. 1996) placed under the $35 \mathrm{~S}$ or T7 promoter. Details of these constructs and infectivity of the PVA chimeras in various host species have been described (Andrejeva et al. 1999; Hämäläinen et al. 2000; Rajamäki and Valkonen 1999). The chimeric viruses are schematically presented in Figure 1 and explained with more details in Results. The PVA mutants in which changes were in-

B11
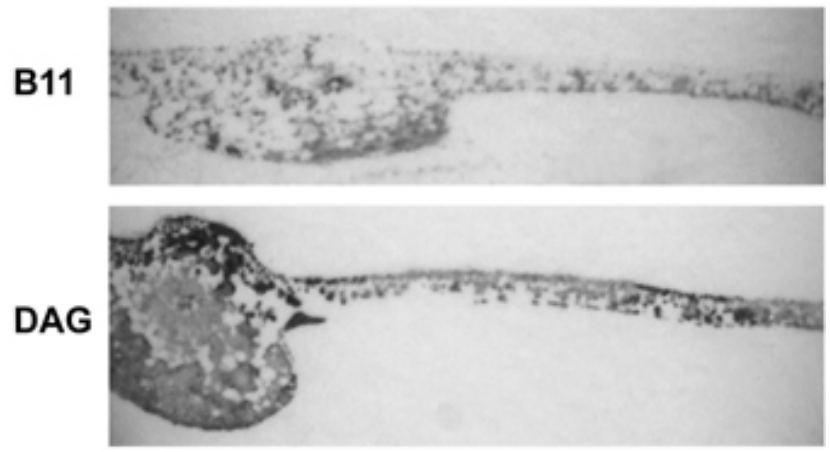

M

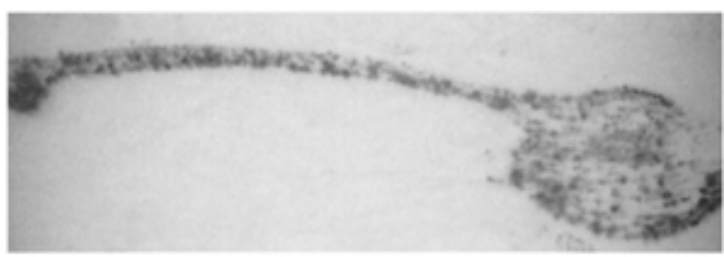

Sab

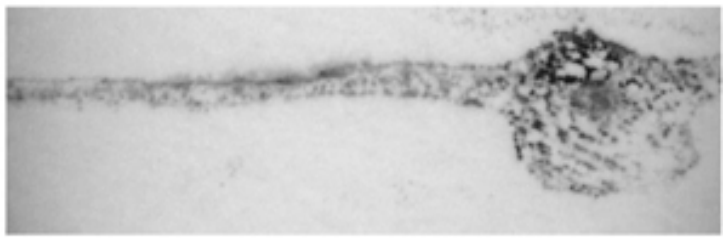

Fig. 4. Detection of three Potato virus A (PVA), isolates (B11, M, and $\mathrm{Sab}$ ) and a mutant of B11 (B11-dag) in systemically infected tobacco leaves 2 days prior to challenge-inoculation with other PVA isolates. The tissue prints of leaf cross-sections prepared on a nitrocellulose membrane were developed using monoclonal antibody (MAb) 58/0 (B11, B11-dag, and $\mathrm{M}$ ) or MAb 58/6 (Sab) specific to PVA coat protein and were photographed under a microscope at a $\times 3$ magnification. The midrib and part of the leaf blade are illustrated. No staining was observed in tissue prints prepared from noninfected leaves (not shown), consistent with no reaction with sap of healthy plants observed with these MAbs in enzyme-linked immunosorbent assay. troduced to the $\mathrm{CP}$ cistron form stabile virions as verified by virus purification or electron microscopy (J. Valkonen, unpublished data).

Stability of the mutations introduced into the cDNAs was verified by RT-PCR-based cloning and sequencing of the mutated areas from progeny viruses after propagation in tobacco plants. Sequencing was done on both strands from at least two independent PCR-amplified clones, as described (Rajamäki and Valkonen 1999).

\section{Plants.}

Tobacco plants (N. tabacum cv. Samsoun nn) (Dunigan et al. 1987) were grown from seeds in a growth chamber $\left(8.8 \mathrm{~m}^{2}\right.$; Weiss Umweltstechnik, Reiskirchen, Germany). The photoperiod $\left(18 \mathrm{~h}, 250 \mu \mathrm{mol} \mathrm{s} \mathrm{m}^{-1}\right)$, temperature $\left(19^{\circ} \mathrm{C}\right.$ day, $17^{\circ} \mathrm{C}$ night), and relative humidity $(40 \%)$ were controlled. Plants were watered daily and fertilized weekly $(0.5 \% \mathrm{~N}: \mathrm{P}: \mathrm{K}=5: 7: 6$ fertilizer).

\section{Virus inoculum.}

Infectious in vitro transcripts were produced from the viral cDNAs placed under the T7 promoter, capped as described (Puurand et al. 1996), and coated on microprojectiles. The cDNA of B11- $\mathrm{M}_{6 \mathrm{KVPg}}$ was placed under the $35 \mathrm{~S}$ promoter, and the plasmid was linearized with AgeI prior to coating on microprojectiles. The cartridges were prepared and inoculations carried out with the Helios Gene Gun System (BioRad Laboratories, Hercules, CA, U.S.A.) using optimized parameters and procedures (Hämäläinen et al. 2000; Kekarainen and Valkonen 2000).

To produce inoculum for experiments, tobacco seedlings (4 to 5 weeks old) were inoculated and the systemically infected leaves harvested 16 dpi. Virus amounts were measured with ELISA (discussed below) and the leaves stored at $-20^{\circ} \mathrm{C}$ to be used for challenge inoculation of the experimental plants. This allowed similar inoculum (i.e., virions) to be used with the natural isolates and the recombinant viruses in different experiments.

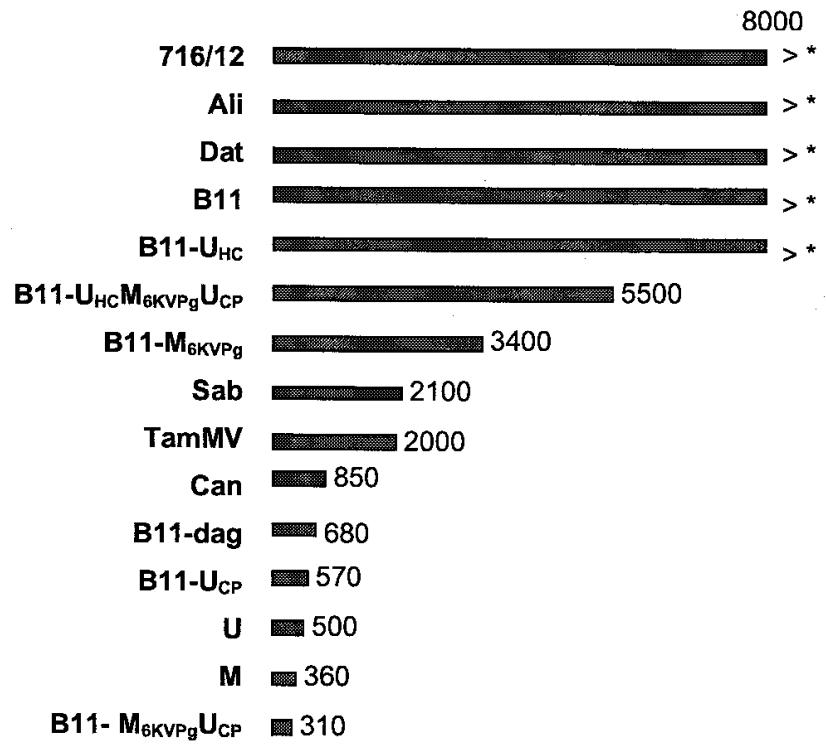

Fig. 5. Amounts of Potato virus $A$ isolates and chimera (coat protein $[\mathrm{CP}$ antigen [ng] per $\mathrm{g}$ of leaf) in systemically infected leaves of tobacco at 16 days postinoculation. Values are representative means calculated based on 8 to 24 plants tested in three to six experiments. The titers of isolates 716/12, Ali, Dat, B11, and the mutant B11- $\mathrm{U}_{\mathrm{HC}}$ are very high (over 8,000 $\mathrm{ng} / \mathrm{g}$ ). 


\section{Inoculation.}

Tobacco seedlings (4 to 5 weeks old) were sap inoculated with the protector isolates. Systemic infection with PVA was usually readily detectable by development of vein clearing in the third and fourth leaf above the inoculated leaf at 13 to 14 dpi. Infection of the fourth leaf also always was verified by ELISA at 16 dpi (discussed below) and, 2 days later, this leaf was challenge inoculated with an inoculum prepared from the frozen tobacco leaves (discussed above). Inocula were adjusted to contain virions at $0.05 \mu \mathrm{g} / \mathrm{ml}$ (diluted with sterile distilled water). Carborundum was used as an abrasive. Each challenger isolate was inoculated to a similar number of protector isolate-infected plants and healthy plants of the same age. One leaf per plant was inoculated at a similar position in each plant. Inoculated leaves were marked with a puncture to the leaf tip. All protector-challenger isolate combinations were tested three times, with each experiment including four tobacco plants per virus combination, unless stated otherwise.

\section{Antibodies.}

Detection of PVA was carried out using the MAb 58/0 or MAb 58/6 (Adgen, Ayr, U.K.) for PVA CP as described previously (Rajamäki et al. 1998). MAb 58/0 recognizes all tobacco strain isolates and the tamarillo strain of PVA, but does not detect the potato strain Sab (Table 2). On the other hand, MAb 58/6 recognizes all potato strains of PVA but does not detect the tobacco strain isolates (except isolate 716/12, which is weakly detected) (Table 2).

\section{Virus detection.}

In most cases, virus detection was carried out using double antibody sandwich (DAS)-ELISA according to standard procedures (Copeland 1998; discussed below). In isolate combinations where the MAbs could not be used to specifically detect the challenger isolate in the presence of the protector, RT-PCR and restriction enzyme analysis of the amplified products (Fig. 3 ), or sequencing, were used to test the presence of the challenge-inoculated virus. Distribution of the protector isolates in systemically infected leaves to be challenge-inoculated were examined using prints of cross-sections of leaves on NCM (Fig. 4) as described by Karyeija and associates (2000).

For DAS-ELISA, approximately $0.5 \mathrm{~g}$ of leaf tissue was excised from the basal part of the fourth leaf above the challengeinoculated leaf at $16 \mathrm{dpi}$. Samples were weighed and were ground in ELISA sample buffer at $1 \mathrm{~g}$ per $3 \mathrm{ml}$, after which two aliquots $(100 \mu \mathrm{l})$ were transferred into two wells of a microtiter plate (Greiner Laborteknik, Frickenhausen, Germany). Known amounts of purified virions of PVA-U (detectable with both MAbs) or PVA-B11 (recognized only by MAb 58/0) were included for comparison to estimate the virus concentrations in leaves. Color reaction was developed using $p$-nitrophenyl phosphate as a substrate. Absorbances were measured at $405 \mathrm{~nm}$ with a Benchmark microtiter plate reader using Microplate Manager software (Bio-Rad) at the time point when the absorbance for $200 \mathrm{ng}$ purified virions reached the $\mathrm{A}_{405}$ value of 2.50. Hence, results from different ELISAs could be readily compared. Quantification of the CP amounts higher than $6.4 \mathrm{ng}$ per $\mathrm{g}$ of leaf was possible by DAS-ELISA, and approximately 10-fold lower amounts could be reliably detected but not quantified.

\section{ACKNOWLEDGMENTS}

We thank M. Zaitlin, Cornell University, Ithaca, NY, U.S.A. for critical evaluation of an earlier version of the manuscript. Financial support from the Academy of Finland (grants 34529 and 36526), the Research Council for Forestry and Agriculture in Sweden (SJFR/Formas grants 32.0667/97 and 301.0663/00), and the research project BIO4-CT97-2356 funded by the European Commission is gratefully acknowledged.

\section{LITERATURE CITED}

Anandalakshmi, R., Marathe, R., Ge, X., Herr, J. M., Jr., Mau, C., Mallory, A., Pruss, G., Bowman, L., and Vance, V. B. 2000. A calmodulin-related protein that suppresses posttranscriptional gene silencing in plants. Science 290:142-144.

Anandalakshmi, R., Pruss, G. J., Ge, X., Marathe, R., Mallory, A. C., Smith, T. H., and Vance, V. B. 1998. A viral suppressor of gene silencing in plants. Proc. Natl. Acad. Sci. U.S.A. 95:13079-13084.

Andrejeva, J., Puurand, Ü., Merits, A., Rabenstein, A., Järvekülg, L., and Valkonen, J. P. T. 1999. Potyvirus HC-Pro and CP proteins have coordinated functions in virus-host interactions and the same $\mathrm{CP}$ motif affects virus transmission and accumulation. J. Gen. Virol. 80:1133-1139.

Angell, S. M., and Baulcombe, D. C. 1997. Consistent gene silencing in transgenic plants expressing a replicating potato virus X RNA. EMBO (Eur. Mol. Biol. Organ.) J. 16:3675-3684.

Atreya, C. D., Atreya, P. L., Thornbury, D. W., and Pirone, T. P. 1992. Sitedirected mutations in the potyvirus HC-PRO gene affect helper component activity, virus accumulation, and symptom expression in infected tobacco plants. Virology 191:106-111.

Beachy, R. N. 1999. Coat protein mediated resistance to tobacco mosaic virus: Discovery, mechanisms and exploitation. Philos. Trans. R. Soc. London B Biol. Sci. 354:659-664.

Bos, L. 1999. Plant Viruses, Unique and Intriguing Pathogens. Backhuys Publishers, Leiden, The Netherlands.

Brigneti, G., Voinnet, O., Li, W-X., Ji, L-H., Ding, S-W., and Baulcombe, D. C. 1998. Viral pathogenicity determinants are suppressors of transgene silencing in Nicotiana benthamiana. EMBO (Eur. Mol. Biol. Organ.) J. 17:6739-6746.

Chiang, C. H., Wang, J. J., Jan, F. J., Yeh, S. D., and Gonsalves, D. 2001. Comparative reactions of recombinant papaya ringspot viruses with chimeric coat protein (CP) genes and wild-type viruses on CP-transgenic papaya. J. Gen. Virol. 82:2827-2836.

Cogoni, C., and Macino, G. 2000. Post-transcriptional gene silencing across kingdoms. Curr. Opin. Genet. Dev. 10:638-643.

Copeland, R. 1998. Assaying levels of plant virus by ELISA. Methods Mol. Biol. 81:455-460.

Dalmay, T., Hamilton, A., Mueller, E. and Baulcombe, D. C. 2000a. Potato virus $X$ amplicons in Arabidopsis mediate genetic and epigenetic gene silencing. Plant Cell 12:369-379.

Dalmay, T., Hamilton, A., Rudd, S., Angell, S., and Baulcombe, D. 2000 b. An RNA-dependent RNA polymerase gene in Arabidopsis is required for posttranscriptional gene silencing mediated by a transgene but not a virus. Cell 101:543-553.

Dalmay, T., Horsefield, R., Hartig Braunstein, T., and Baulcombe, D. C. 2001. SDE3 encodes an RNA helicase required for post-transcriptional gene silencing in Arabidopsis. EMBO (Eur. Mol. Biol. Organ.) J. 20:2069-2077.

Dolja, V. V., Haldeman, R., Robertson, N. L., Dougherty, W. G., and Carrington, J. C. 1994. Distinct functions of capsid protein in assembly and movement of tobacco etch potyvirus in plants. EMBO (Eur. Mol. Biol. Organ.). 13:1482-1491.

Dougherty, W. G., and Parks, T. D. 1995. Transgenes and gene suppression: Telling us something new? Curr. Opin. Cell Biol. 7:399-405.

Dunigan, D. D., Golemboski, D. B., and Zaitlin, M. 1987. Analysis of the $N$ gene of Nicotiana. Pages 120-135 in: Plant Resistance to Viruses (Ciba Foundation Symposium 133). D. Evered and S. Harnett, eds. John Wiley \& Sons, Chichester, U.K.

Eagles, R. M., Gardner, R. C., and Forster, R. L. S. 1990. Nucleotide sequence of the tamarillo mosaic virus coat protein gene. Nucleic Acids Res. 18:7166.

Elbashir, S. M., Harborth, J., Lendeckel, W., Yalcin, A., Weber, K., and Tuschl, T. 2001. Duplexes of 21-nucleotide RNAs mediate RNA interference in cultured mammalian cells. Nature 411:494-498.

English, J. J., Müller, E., and Baulcombe, D. C. 1996. Suppression of virus accumulation in transgenic plants exhibiting silencing of nuclear genes. Plant Cell 8:179-188.

Fagard, M., Boutet, S., Morel, J.-B., Bellini, C. and Vaucheret, H. 2000. AGO1, QDE-2, and RDE-1 are related proteins required for posttranscriptional gene silencing in plants, quelling in fungi, and RNA interference in animals. Proc. Natl. Acad. Sci. U.S.A. 97:1165011654.

Fraser, R. S. S. 1998. Introduction to classical crossprotection. Pages 1324 in: Methods in Molecular Biology, vol. 81: Plant Virus Protocols. G. D. Foster and S. C. Taylor, eds. Humana Press, Totowa, NJ, U.S.A.

Fulton, R. W. 1978. Superinfection by strains of tobacco streak virus. Virology 85:1-8.

Gerber, M., and Sarkar, S. 1989. The coat protein of tobacco mosaic virus does not play a significant role for cross-protection. J. Phytopathol. $124: 323-331$. 
Goodwin, J., Chapman, K., Swaney, S., Parks, T. D., Wernsman, E. A., and Dougherty, W. G. 1996. Genetic and biochemical dissection of transgenic RNA-mediated virus resistance. Plant Cell 8:95-105.

Gonsalves, D. 1998. Control of papaya ringspot virus in papaya: A case study. Annu. Rev. Phytopathol. 36:415-437.

Haldeman-Cahill, R., Daros, J.-A., and Carrington, J. C. 1998. Secondary structures in the capsid protein coding sequence and $3^{\prime}$ nontranslated region involved in amplification of the tobacco etch virus genome. J. Virol. 72:4072-4079.

Hämäläinen, J. H., Kekarainen, T., Gebhardt, C., Watanabe, K. N., and Valkonen, J. P. T. 2000. Recessive and dominant genes interfere with the vascular transport of Potato virus A in diploid potatoes. Mol. PlantMicrobe Interact. 13:402-412.

Hamilton, A. J., and Baulcombe, D. C. 1999. A species of small antisense RNA in posttranscriptional gene silencing in plants. Science 286:950952

Hari, V. 1981. The RNA of tobacco etch virus: Further characterization and detection of protein linked to RNA. Virology 112:391-399.

Karyeija, R. F., Kreuze, J. F., Gibson, R. W., and Valkonen, J. P. T. 2000. Synergistic interactions of a potyvirus and a phloem-limited crinivirus in sweet potato plants. Virology 269:26-36

Kasschau, K. D., and Carrington, J. C. 1998. A counterdefensive strategy of plant viruses: Suppression of posttranscriptional gene silencing. Cell 95:461-470

Kasschau, K. D., and Carrington, J. C. 2001. Long-distance movement and replication maintenance functions correlate with silencing suppression activity of potyviral HC-Pro. Virology 285:71-81.

Kekarainen, T., Merits, A., Oruetxebarria, I., Rajamäki, M.-L., and Valkonen, J. P. T. 1999. Comparison of the complete sequences of five different isolates of Potato virus A (PVA), genus Potyvirus. Arch. Virol. 144:2355-2366.

Kekarainen, T., and Valkonen, J. P. T. 2000. Inoculation of viral RNA and cDNA to potato and tobacco plants using the Helios Gene Gun. Tech. Note 2351. Bio-Rad Laboratories, Hercules, CA, U.S.A.

Leonard, S., Plante, D., Wittmann, S., Daigneault, N., Fortin, M. G., and Laliberte, J.-F. 2000. Complex formation between potyvirus VPg and translation eukaryotic initiation factor $4 \mathrm{E}$ correlates with virus infectivity. J. Virol. 74:7730-7737.

Lindbo, J. A., Silva-Rosales, L., Proebsting, W. M., and Dougherty, W. G. 1993. Induction of a highly specific antiviral state in transgenic plants: Implication for regulation of gene expression and virus resistance. Plant Cell 5:1749-1759.

Lu B., Stubbs, G., and Culver, J. N. 1998. Coat protein interactions involved in tobacco mosaic tobamovirus cross-protection. Virology 248:188-198.

Mahajan, S., Dolja, V. V., and Carrington, J. C. 1996. Roles of the sequence encoding tobacco etc virus capsid protein in genome amplification: Requirements for the translation process and a cis-acting element. J. Virol. 70:4370-4379

Mallory, A. C., Ely, L., Smith, T. H., Marethe, R., Anandalakshmi, R., Fagard, M., Vaucheret, H., Pruss, G., Bowman, L., and Vance, V. B. 2001. HC-Pro suppression of transgene silencing eliminates the small RNAs but not transgene methylation or the mobile signal. Plant Cell 13:571-583.

Matthews, R. E. F. 1991. Pages 145, 439-450, and 503-510 in: Plant Virology. Academic Press, New York.

McKinney, H. H. 1929. Mosaic diseases in the Canary Islands, West Africa and Gibraltar. J. Agric. Res. 39:557-578.

Merits, A., Guo, D., and Saarma, M. 1998. VPg, coat protein and five nonstructural proteins of potato A potyvirus bind RNA in a sequence-unspecific manner. J. Gen. Virol. 79:3123-3127.

Moore, C. J, Sutherland, P. W., Forster, R. L. S., Gardner, R. C., and MacDiarmid, R. M. 2001. Dark green islands in plant virus infection are the result of posttranscriptional gene silencing. Mol. Plant-Microbe Interact. 14:939-946.

Mourrain, P., Béclin, C., Elmayan, T., Feuerbach, F., Godon, C., Morel, J.B., Jouette, D., Lacombe, A.-M., Nikic, S., Picault, N., Rémoué, K., Sanial, M., Vo, T.-A., and Vaucheret, H. 2000. Arabidopsis SGS2 and SGS3 genes are required for posttranscriptional gene silencing and natural virus resistance. Cell 101:533-542.
Novak, J. E., and Kirkegaard, K. 1994. Coupling between genome translation and replication in an RNA virus. Genes Dev. 8:1726-1737.

Oruetxebarria, I., Guo, D., Merits, A., Mäkinen, K., Saarma, M., and Valkonen, J. P. T. 2001. Identification of the genome-linked protein of a Potato virus A, with comparison to other members of genus Potyvirus. Virus Res. 73:103-112.

Paul, A. V., van Boom, J. H., Filippov, D., and Wimmer, E. 1998. Proteinprimed RNA synthesis by purified poliovirus RNA polymerase. Nature 293:280-294.

Puurand, Ü., Mäkinen, K., Paulin, L., and Saarma, M. 1994. The nucleotide sequence of potato virus A genomic RNA and its sequence similarities with other potyviruses. J. Gen. Virol. 75:457-461.

Puurand, Ü., Valkonen, J. P. T., Mäkinen, K., Rabenstein, F., and Saarma, M. 1996. Infectious in vitro transcripts from cloned cDNA of the potato A potyvirus. Virus Res. 40:135-140.

Rajamäki, M., Merits, A., Rabenstein, F., Andrejeva, J., Paulin, L., Kekarainen, T., Kreuze, J. F., Forster, R. L. S., and Valkonen, J. P. T. 1998. Biological, serological, and molecular differences among isolates of Potato A potyvirus. Phytopathology 88:311-321.

Rajamäki, M.-L., and Valkonen, J. P. T. 1999. The 6K2 protein and the VPg of Potato virus A are determinants of systemic infection in Nicandra physaloides. Mol. Plant-Microbe Interact. 12:1074-1081.

Rajamäki, M-L., and Valkonen, J. P. T. 2002. Viral genome-linked protein (VPg) controls accumulation and phloem-loading of a potyvirus in inoculated potato leaves. Mol. Plant-Microbe Interact. 15:138-149.

Rast, A. T. B. 1972. MII-6, an artificial symptomless mutant of tobacco mosaic virus for seedling inoculation of tomato crops. Neth. J. Plant Pathol. 78:110-112.

Ratcliff, F. G., MacFarlane, S., and Baulcombe, D. C. 1999. Gene silencing without DNA: RNA-mediated cross-protection between viruses. Plant Cell 11:1207-1215.

Rezende, J. A. M., and Pacheco, D. A. 1998. Control of papaya ringspot virus-type $\mathrm{W}$ in zucchini squash by cross-protection in Brazil. Plant Dis. $82: 171-175$

Riechmann, J. L., Laín, S., and Garcia, J. A. 1989 The genome-linked protein and 5' RNA sequence of plum pox potyvirus. J. Gen. Virol. 70:2785-2789.

Sherwood, J. L., and Fulton, R. W. 1982. The specific involvement of coat protein in tobacco mosaic virus (TMV) cross protection. Virology 119:150-158.

Shukla, D. D., Ward, C. W., and Brunt, A. A. 1994. The Potyviridae. CAB International, Wallingford, U.K.

Suzuki, N., Kudo, T., Shirako, Y., Ehara, Y., and Tachibana, T. 1989. Distribution of cylindrical inclusion, amorphous inclusion, and capsid proteins of watermelon mosaic virus 2 in systemically infected pumpkin leaves. J. Gen. Virol. 70:1085-1091.

Valkonen, J. P. T. 2002. Natural resistance to viruses. Pages 367-397 in Plant Viruses as Molecular Pathogens. J. A. Khan and J. Dijkstra, eds. Haworth Press Inc., New York.

Valkonen, J. P. T., Puurand, Ü., Slack, S. A., Mäkinen, K., and Saarma, M. 1995. Three strain groups of potato A potyvirus based on hypersensitive responses in potato, serological properties, and coat protein sequences Plant Dis. 79:748-753.

Voinnet, O., Lederer, C., and Baulcombe, D. C. 2000. A viral movement protein prevents spread of the gene silencing signal in Nicotiana benthamiana. Cell 103:157-167.

Voinnet, O., Pinto, Y. M., and Baulcombe, D. C. 1999. Suppression of gene silencing: A general strategy used by diverse DNA and RNA viruses. Proc. Natl. Acad. Sci U.S.A. 96:14147-14152.

Wang, X., Ullah, Z., and Grumet, R. 2000. Interaction between zucchini yellow mosaic potyvirus RNA-dependent RNA polymerase and host poly-(A) binding protein. Virology 275:433-443.

Waterhouse, P. M., Wang, M.-B., and Lough, T. 2001. Gene silencing as an adaptive defense against viruses. Nature 411:834-842.

Xie, Z., Fan, B., Chen, C., and Chen, Z. 2001. An important role of an inducible RNA-dependent RNA polymerase in plant antiviral defense. Proc. Natl. Acad. Sci. U.S.A. 98:6516-6521.

Yamaya, J., Yoshioka, M., Meshi, T., Okada, Y., and Ohno, T. 1988. Cross protection in transgenic tobacco plants expressing a mild strain of tobacco mosaic virus. Mol. Gen. Genet. 215:173-175. 